\title{
THE IMPACT OF SKILLED MIGRATION ON FOREIGN QUALIFICATION RECOGNITION REFORM IN AUSTRALIA
}

\author{
Author name: $\quad$ Lesleyanne Hawthorne \\ Author affiliation: University of Melbourne \\ Date: \\ FINAL 14 July 2015 \\ Submitted for: Immigration and Regulated Professions \\ Special Issue \\ Canadian Public Policy
}

\begin{abstract}
Keywords: Australia; skilled migrants; professional regulation; medicine; nursing

This paper has four aims. First, it defines the extent to which skilled migration to Australia has changed in recent decades in terms of scale, source country, and entry mode. Second, it describes Australia's federally-driven foreign qualification recognition (FQR) reform strategy, including the pressure imposed by successive parliamentary reviews to improve outcomes. Third, it reports the growing engagement of select health regulators in reform, at a time when temporary workers constitute three-quarters of skilled migrants, and the question increasingly asked is whether regulatory bodies have the agility to facilitate labour migration flows. Finally, it assesses the contribution of qualification recognition reform to skilled migrants' recognition and early employment outcomes. Key learnings from Australia's FQR experience are then highlighted, of potential policy relevance to Canada.
\end{abstract}




\section{THE IMPACT OF SKILLED MIGRATION ON FOREIGN QUALIFICATION RECOGNITION REFORM IN AUSTRALIA}

In an age of transnationalism, growing numbers of professionals are born in one country, educated in other/s, then leverage off their skills to secure employment anywhere in the world. Within this context extraordinary recent attention has been paid to foreign qualification recognition (FQR). Regulatory systems in the major immigrant receiving countries were largely designed in the nineteenth century, when the speed, scale and complexity of twenty-first century mobility were unimaginable. The demand for greater flexibility in recognition practices is now growing, at a time when:

- Employers seek more agile and responsive accreditation systems, matched to contemporary migration modes and sector needs.

- Governments urge regulatory bodies to change, to maximize employment and social justice outcomes.

- Globally mobile professionals advocate to be able to use their skills, including when relocating on a temporary rather than on a permanent resident basis.

In the recent decade the OECD has articulated the case for FQR reform through comparative country and field-specific analyses - many with an economic efficiency focus. In 2008 a UNESCO commissioned study compared approaches in select European, North American, Asia-Pacific and African countries, subsequently expanded pan-Asia. The International Organization of Migration has defined FQR strategies and best practice initiatives in major immigrant-receiving countries (Australia, Canada, USA) compared to the European Union (Denmark, Germany, Italy, the Netherlands, Sweden, UK). The World Health Organization and ILO have initiated cycles of studies to assess health workforce migration, considering the extent to which recognition fuels brain wastage compared to effective human capital transfer. The US Migration Policy Institute in 2013 released a cycle of FQR studies, examining global policy innovation and change, including how changing migration modes are now influencing recognition processes (OECD, 2005; WHO, 2006; Zurn and Dumont, 2008; Hawthorne, 2008, 2013; Schuster and Desiderio, 2013; Sumption, 2013; Siyam and Del Paz, 2014).

At the national level, governments have sought greater transparency and consistency through the establishment of national accreditation and assessment bodies. They have developed frameworks to facilitate the matching of overseas qualifications, and commissioned reviews to spur reform. In-depth field-specific studies have been conducted in select countries - for example Germany, the Netherlands and Australia in relation to health (Englmann and Muller, 2007; Herfs, 2011; Hawthorne et al, 2007). Regulatory bodies have come under increasing pressure to adapt - driven by the scale of migration in key fields, the growing dominance of temporary flows, the negotiation of bilateral and multilateral agreements, and the development of national and/or regional reform agendas. Innovative approaches are being trialled to fast-track qualification assessment, to allow individuals to work on a limited licensure base, and to create alternative pre-registration pathways (most notably for foreign temporary workers admitted on a sponsored basis). As noted by the Migration Policy Institute, however, 'Barriers to the transferability of foreign qualifications are both widely acknowledged and stubbornly persistent... While various policies have emerged to improve 
the recognition of foreign qualifications, no country can claim to have "solved" the problem, and many of the efforts to address it are still in their infancy' (Sumption, 2013: 2)

Against this policy backdrop a substantial literature has evolved in recent decades on the impact of 'professional protectionism' on assessment, given that recognition can be contaminated by a desire to minimise competition from 'outsiders'. In his seminal study, Professional Powers: A Study of the Institutionalization of Formal Knowledge, Freidson defined professional groups as 'the creators and proponents of particular bodies of knowledge', in a societal context where 'Knowledge becomes power, and (the) profession stands as the human link between the two'. In utilising such power, professional bodies may come to exert 'a pervasive social control' masked by 'benevolence' - separating knowledge into credentialled and uncredentialled forms, and endorsing the 'norms' it has become appropriate to value. According to Freidson, the professions' goal within this process is invariably self-serving (despite claims to protect the public and serve its interests). It is to gain a 'secure and privileged place in the economy' of host countries, through the formation of an 'exclusionary shelter in the market in which (members once) had to compete with rival occupations'. As part of this strategy, bodies laud their members' attitudes and skills promoting them 'as honoured servants of public need', dedicated to occupations 'especially distinguished from others... through the schooled application of their unusually... complex knowledge'. A notion of skills hierarchy is integral to this process: the assignment of superior or inferior status to different qualifications, whether acquired in-country or from overseas (Freidson 1986: ix-33; Freidson, 1994). The impacts on migrants can be severe - described in Canada, for instance, as 'democratic racism' based on 'a deficit model of difference', with comparable critiques also mounted in Australia (Guo, 2007: 37; Iredale, 2009).

\section{AUSTRALIAN SKILLED MIGRATION TRENDS IN THE PAST DECADE}

While the concept of professional protectionism is entrenched in the qualification recognition literature, there has been minimal examination to date of the extent to which professional bodies in the early twenty-first century are now driving qualification recognition. This is a growing phenomenon in Australia in select fields, following three decades of governmentinstigated reform and rapid changes to migration entry pathways. In terms of migration five key trends should be noted, drawing on the latest Australian data.

Scale of flows: First, the scale of skilled migration to Australia has transformed since 1999, with marked impact on the regulated professions and trades. By $201162 \%$ of residents with engineering degrees were overseas-born, compared to 57\% of IT professionals, $53 \%$ of accountants, $47 \%$ of doctors and $29 \%$ of nurses (compared to $26 \%$ of the population). Around a third had migrated in the previous five years, including 41,407 engineers, 35,423 accountants, 31,969 IT professionals, 26,348 nurses and 12,696 doctors. (See Table 1.) In 2014-15 a further 128,550 skilled category permanent migrants will be accepted - including 48,250 who are employer-sponsored, 43,990 Independents, and 28,850 state/ territory nominated arrivals.

Dominance of temporary entry: Second, in a dramatic reversal of past patterns the majority of skilled migrants to Australia in the recent decade have been admitted on a temporary rather than a permanent resident basis (up to 74\%). In 2013-14 108,870 457 visa temporary migrants were directly sponsored to pre-arranged work, in a year when 38,130 permanent skilled migrants were admitted as primary applicants (PA's), this number excluding partners 
and children typically counted within 'the migration unit'. Large numbers are unwilling to invest in full qualification recognition - their preferred options being limited scope of practice, conditional registration, or restricted practice time frames (Hawthorne, 2013). (See Table 2.)

Table 1: Growth in Migration to Australia by Major Professional Field (2006-August 2011 Compared to 2001-2005, All Immigration Categories)

\begin{tabular}{|l|r|r|}
\hline Field & $\begin{array}{r}\text { January 2001- December 2005 } \\
\text { Arrivals }\end{array}$ & $\begin{array}{r}\text { January 2006-August 2011 } \\
\text { Arrivals }\end{array}$ \\
\hline Engineering & 18,790 & 41,407 \\
\hline Accounting & 26,145 & 35,423 \\
\hline Information Technology & 22,630 & 31,968 \\
\hline Education & 15,400 & 29,464 \\
\hline Registered Nursing (Degrees) & 8,584 & 16,154 \\
\hline Registered Nursing (Diplomas) & 5,649 & 10,194 \\
\hline Medicine & 7,241 & 12,696 \\
\hline Pharmacy & 1,798 & 3,005 \\
\hline Dentistry & 1,063 & 2,343 \\
\hline Physiotherapy & 755 & 1,556 \\
\hline Total (All Degrees) & 192,940 & 347,611 \\
\hline
\end{tabular}

Source: Analysis of unpublished data from the August 2011 Census, provided by the Australian Bureau of Statistics.

Table 2: Australian Employer Demand for Skilled Migrants, Temporary Compared to Permanent Categories, by Major Field and Selection Location (30 June 2008 to 30 June 2014)

\begin{tabular}{|l|r|r|r|r|r|r|r|}
\hline Skilled Category & $\mathbf{2 0 0 8 - 0 9}$ & $\mathbf{2 0 0 9 - 1 0}$ & $\mathbf{2 0 1 0 - 1 1}$ & $\mathbf{2 0 1 1 - 1 2}$ & $\mathbf{2 0 1 2 - 1 3}$ & $\mathbf{2 0 1 3 - 1 4}$ & \% Selected Onshore \\
\hline $\begin{array}{l}\text { Temporary Stock } \\
\text { Resident (457 Visa) }\end{array}$ & & & & & & & $\begin{array}{r}\text { \% New Approvals } \\
\text { (2013-14 Only) }\end{array}$ \\
\hline Computing/ IT & 7,150 & 7,360 & 9,010 & 10,490 & 11,050 & 10,880 & $22.2 \%$ \\
\hline Engineering & 6,670 & 5,620 & 6,210 & 8,280 & 8,070 & 6,160 & $39.8 \%$ \\
\hline Accounting & 2,580 & 2,470 & 2,710 & 3,330 & 3,840 & 4,010 & $48.9 \%$ \\
\hline Nursing & 4,560 & 3.850 & 3,300 & 4,070 & 4,770 & 3,810 & $61.6 \%$ \\
\hline Medicine & 5,060 & 4,600 & 4,990 & 5,030 & 4,590 & 4,160 & $34.7 \%$ \\
\hline Education & 1,220 & 1,130 & 1,420 & 2,190 & 2,830 & 2,910 & $50.8 \%$ \\
\hline Total (all fields) & 77,300 & 68,400 & 72,030 & 91,050 & 107,970 & 108,870 & $50.9 \%$ \\
\hline $\begin{array}{l}\text { Permanent Arrivals } \\
\text { (GSM Visa) }\end{array}$ & & & & & & & \% + Total \\
\hline Computing/ IT & 4,774 & 5,205 & 4,468 & 8,538 & 8,389 & 7,975 & $37.2(39,349)$ \\
\hline Engineering & 4,319 & 5,907 & 4,112 & 4,891 & 3,898 & 4,160 & $35.2(27,287)$ \\
\hline Accounting & 6,642 & 6,783 & 14,949 & 7,303 & 6,022 & 6,880 & $70.1(48,579)$ \\
\hline Nursing & 1,357 & 1,700 & 1,374 & 1,174 & 1,404 & 2,761 & $57.5(9,770)$ \\
\hline Medicine & 446 & 1,070 & 508 & 1,037 & 1,289 & 1,134 & $28.8 \%(5,484)$ \\
\hline Education & 883 & 754 & 467 & 730 & 912 & 961 & $37.5(4,707)$ \\
\hline Total (all fields) & 33,604 & 28,042 & 34,913 & 36,893 & 39,147 & 38,130 & $50.0(210,729)$ \\
\hline
\end{tabular}

Source: Analysis of unpublished Department of Immigration and Border Control immigration arrivals data for permanent compared to temporary skilled migration categories, provided August 2014.

Study-migration pathway: Third, Australian employers now demonstrate a keen interest in the study-migration pathway, despite their level of take-up being highly variable by field. In 
the year to 30 June 2014, 50\% of permanent skilled migrants and 51\% of temporary foreign workers were selected within Australia - the great majority as former international students. By definition students qualified in Australia face no recognition barriers. Within the temporary 457 visa category (where migrants work up to four years in under-supplied sectors or sites) onshore sponsorship rates to June 2014 included $62 \%$ of nursing, $49 \%$ of accountancy, $40 \%$ of engineering, 35\% of medical, and $22 \%$ of computing/IT approvals. Within the permanent skilled category, onshore selection ranged from $70 \%$ of accountancy to $58 \%$ of nursing, $37 \%$ of computing/IT, $35 \%$ of engineering and $29 \%$ of medical migrants (noting that mature experience / specialist training in engineering and medicine were clearly valued). By 2011 former international students qualified in medicine, dentistry and pharmacy achieved stellar employment outcomes within four months of graduation if remaining in Australia (near identical rates to local students). In medicine $99 \%$ had gained fulltime work, along with $96 \%$ of dental and pharmacy students and $66 \%$ of nursing students. (See Table 3.) (By contrast $57 \%$ of medical, 32\% of dental and $66 \%$ of nursing migrants secured employment in their field in their first five years in Australia, selected across all immigration categories.) Outcomes were far less impressive in oversupplied fields, such as business and accounting. The study-migration pathway will not be further analysed here, but should be noted as a key Australian strategy to minimise qualification recognition barriers (Hawthorne \& To, 2014).

Table 3: International Student Employment Outcomes in Australia Relative to Domestic Student Graduates with Bachelor Degrees Four Months After Graduation (2009 to 2011)

\begin{tabular}{|c|c|c|c|c|c|c|c|c|c|}
\hline \multirow[b]{2}{*}{ Activity } & \multicolumn{4}{|c|}{ Domestic Students } & \multicolumn{4}{|c|}{ International Students } & \multirow{2}{*}{$\begin{array}{r}\text { Total } \\
2009- \\
2011\end{array}$} \\
\hline & 2009 & 2010 & 2011 & Total & 2009 & 2010 & 2011 & Total & \\
\hline & & & & & & & & & Medicine \\
\hline Working FT (\%) & 99.5 & 99.8 & 99.7 & 99.7 & 96.9 & 98.8 & 100 & 98.8 & 99.6 \\
\hline Available for FT work (N) & 744 & 842 & 1144 & 2730 & 98 & 165 & 161 & 424 & 3154 \\
\hline \multicolumn{10}{|c|}{ Pharmacy } \\
\hline Working FT (\%) & 97.9 & 97.4 & 97.5 & 97.6 & 98.3 & 96.6 & 93.1 & 96.1 & 97.3 \\
\hline Available for FT work (N) & 481 & 538 & 484 & 1503 & 116 & 89 & 102 & 307 & 1810 \\
\hline \multicolumn{10}{|c|}{ Accounting } \\
\hline Working FT (\%) & 86.3 & 80.9 & 81.1 & 82.7 & 41.7 & 32.9 & 31.6 & 35.2 & 69.6 \\
\hline Available for FT work (N) & 3213 & 3233 & 3373 & 9819 & 1193 & 1211 & 1340 & 3744 & 13563 \\
\hline \multicolumn{10}{|c|}{ Business / Commerce } \\
\hline Working FT (\%) & 77.2 & 75.6 & 76.4 & 76.4 & 39.4 & 39.4 & 40.3 & 39.7 & 72.9 \\
\hline Available for FT work (N) & 6282 & 6665 & 7035 & 19982 & 672 & 649 & 780 & 2101 & 22083 \\
\hline \multicolumn{10}{|c|}{ Information Technology } \\
\hline Working FT (\%) & 79.9 & 74.8 & 79.1 & 78.0 & 43.3 & 43.5 & 40.1 & 42.3 & 71.2 \\
\hline Available for FT work (N) & 1704 & 1566 & 1592 & 4862 & 397 & 347 & 394 & 1138 & 6000 \\
\hline \multicolumn{10}{|c|}{ Engineering } \\
\hline Working FT (\%) & 88.3 & 84 & 86.7 & 86.4 & 51.1 & 39.5 & 40.5 & 43.6 & 80.8 \\
\hline Available for FT work (N) & 2708 & 2455 & 2652 & 7815 & 372 & 334 & 467 & 1173 & 8988 \\
\hline \multicolumn{10}{|c|}{ All Disciplines } \\
\hline Working FT (\%) & 79.3 & 76.6 & 76.8 & 77.5 & 50.9 & 46.4 & 43.2 & 46.7 & 46.7 \\
\hline Available for FT work (N) & 39174 & 39448 & 41506 & 120128 & 4194 & 4268 & 4675 & 13137 & 13137 \\
\hline
\end{tabular}

Source: Analysis of Australia's Graduate Destination Survey responses 2009-11, L Hawthorne, \& A To, A (2014), 'Employer Response to the Study-Migration Pathway: The Australian Evidence 2007-2011', International Migration, 52(3). 
Family and humanitarian arrivals: Finally, while the majority of degree and diplomaqualified migrants are admitted through Australia's skilled categories, the provision of onshore foreign qualification recognition strategies remains vital to cater to migrants unscreened in advance for human capital attributes - entering as skilled applicants' partners, family or humanitarian category arrivals. In 2014-15 Australia will admit 213,000 permanent migrants overall. The majority of the 60,885 family and 13,000 humanitarian entrants with qualifications will commence the process of English and FQR assessment in Australia. Many face years of occupational displacement.

\section{AUSTRALIAN GOVERNMENT-DRIVEN REFORM FROM THE 1980s}

The process of Australian qualification recognition reform commenced in 1983 with the report of the government-commissioned Committee of Inquiry on the Recognition of Overseas Qualifications (CIROQ). In brief, FQR processes at this time were shown to flout notions of equity - including the entitlement of non-English speaking background migrants to fair, consistent and transparent judgments, to mount appeals, and to secure assessment of specialist rather than baseline qualifications. Skilled migrants required access to counselling, and preparation for examination processes, supported by the provision of professional or trade placements. Most notably, there was deemed an urgent need to define and review the ways in which 'standards' were set by professional bodies (whose role was severely critiqued), and to establish these on a national basis - ending the piecemeal state-specific system which had evolved over time (CIROQ, 1983).

Responding to this and subsequent reviews, the Australian government introduced major FQR reforms from 1989 - federally led, supported by significant public funding, and based on multi-sector input (including state governments, accreditation and regulatory bodies, education providers, peak trade union and migration bodies). Nine priority professions and trades were targeted to develop nationally agreed competency standards, supported by fieldspecific bridging programs (Gonczi et al, 1989; Department of Employment Education and Training, 1992). By the mid-1990s, for example, the New South Wales Migrant Skills and Qualifications Committee was publishing a 120 page annual listing of courses in that state alone. Ten national bridging models for engineers existed, around half with a qualification recognition focus. Three month competency-based courses were introduced for migrant nurses, aligning theory with clinical training, to result in full registration. Participation in Western Australia transformed a 74\% examination failure rate (across 10 years) to an 89\% pass rate, compared to $90-95 \%$ and $55-77 \%$ pass rates in Victoria and New South Wales respectively (Hawthorne, 1994, 2002). By 201336 bridging course models were offered nationally for migrant nurses, delivered on a fee-for-service or loan basis through the tertiary, vocational training and clinical sectors (Chiongma, 2012).

To better inform qualification assessment, the federal government established the National Office of Overseas Skills Recognition (NOOSR) within its labour and employment department. Country Education Profiles were developed to define the calibre of education and training in source countries, and facilitate benchmarking against Australian standards. By 2015 'authoritative information for 127 countries from Africa, Asia Pacific, Europe, Subcontinent and the Middle East and the Americas' was provided, including 'lists of institutions recognised by the relevant country authority (and) key quality indicators' (Department of Education and Training, 2015). Peak field-specific pre-migration assessment bodies were established. An Australian Qualifications Framework was implemented from 
2000, to enhance mapping of global against national standards, and act as a reference point for licensing and regulatory bodies. Two expert bodies were established to improve vocational assessment - the Trade Regulation Authority (within the federal employment department) and VETAssess (with representation in over 20 immigrant source countries, and a capacity to provide pre-migration Australian-accredited 'gap-training').

\section{PARLIAMENTARY FQR REVIEWS (1996-2012)}

Multiple additional reforms could be noted - the majority of these strategies federally-led and funded. Many were innovative for their time, with select models globally influential. Notwithstanding this, successive Australian governments remained vigilant and critical, with three parliamentary reviews commissioned to monitor outcomes.

1996: Five years following the introduction of Australia's reform agenda, the National Office of Overseas Skills Recognition concluded persistent barriers to foreign qualifications recognition remained, despite the establishment of 'structured pathways to recognition' for 'the overwhelming majority of occupations at the professional, para-professional, technical and trade levels' (NOOSR 1994: 3, 7-8). Two years later a Parliamentary review with a strong FQR focus (A Fair Go For All - Report on Migrant Access and Equity), confirmed the achievement of minimal gains since 1983, noting a continued 'automatic devaluing of qualifications and skills acquired from non-English speaking background countries' despite improvement in nursing, engineering and trade outcomes (HRSCCA 1996: 60, 84). Given the legal impossibility of controlling regulatory bodies' practice, their expanded role in the assessment of skilled migrants was recommended (implemented from 1999). Primary applicants at risk of non-recognition would in future be ineligible to migrate, through the extension of mandatory English language testing and pre-migration qualifications assessment.

2006: In 2006 Parliament's Joint Standing Committee on Migration was commissioned to exhaustively review foreign qualification recognition barriers, investigating requirements by key vocational field. The resulting report (Negotiating the Maze - Review of Arrangements for Overseas Skills Recognition, Upgrading and Licensing) made 55 recommendations to reduce complexity for migrants, while maximising their speed of employment outcomes. Key measures included improved policy coordination; ongoing research on overseas qualification utilisation in work; the provision of clearer information on field-specific requirements; minimisation of red tape and process duplication; a national audit of bridging programs by field (spanning level of take-up and impacts); and the extension of Australia's tertiary education loans scheme to support re-training for permanent migrants (Joint Standing Committee on Migration, 2006: xvii-xxviii).

2012: From 2010-12 a House of Representatives review focused solely on medicine, in a context where Australia had developed disproportionate reliance on migrants to work in undersupplied sectors and sites - the great majority recruited on a temporary resident basis. The resulting report (Lost in the Labyrinth - Inquiry into Registration Processes and Support for Overseas Trained Doctors) mounted a powerful critique of FQR processes, at a time when sponsored medical migrants immediately transitioned to work, many on a conditionally registered basis. Key concerns included:

- Process duplication between the national assessment (Australian Medical Council) and registration (Medical Board of Australia) bodies, since the 2010 introduction of Australia’s uniform National Law. 
- The defensibility of the standards required for medical registration.

- The type and scope of examinations used, including their match to clinical practice requirements.

- The stability and reliability of these instruments.

- The length of test result validity (given delays to document verification, and extensive examination waitlists).

- The quality of rater training.

- Scope for candidate appeal (including the mode, cost and transparency of processes).

- Access to exam preparation and bridging training.

- Provision of candidate feedback to improve future performance.

- Specialist college assessment processes (House of Representatives Standing Committee on Health and Ageing, 2012).

In the past decade Australian employers have secured unprecedented power to sponsor migrants to pre-arranged employment. Successive governments have prioritized skilled migration, while seeking to maximize economic outcomes. Regulatory bodies' core value remains the protection of public safety. At the same time they have faced sustained pressure to adapt and accommodate the reality of $21^{\text {st }}$ century migration. A number are now driving FQR change, illustrated below by three health sector case studies ${ }^{\mathrm{i}}$.

\section{CASE STUDY 1 (MEDICINE) - CREATING ALTERNATIVE REGISTRATION PATHWAYS}

By 2011 migrants constituted 59\% of Australians with dental degrees, 47\% of doctors, and $29 \%$ of nurses. Australia's level of reliance shows minimal sign of abating. The latest data for the year to June 2014 reveals 4,719 doctors, nurses and dentists selected as permanent skilled migrants (compared to a total of 1,935 in 2008-09). More notably 8,120 temporary migrants were resident that year, working on temporary 457 visas (compared to 2,780 in 2008-09) (Department of Immigration and Border Protection, 2014).

In 2007 a study commissioned by the federal health department analysed international medical graduates' (IMGs) 1978-2005 registration outcomes by key variables, assessing the impact on candidate pass rates of place of training, age, gender and language background. Candidates by this time were extraordinarily diverse, derived from 139 source countries (most notably India, Sri Lanka, Egypt, Bangladesh, China and the UK). Overall, 81\% who attempted the MCQ would eventually pass it (51\% on their first attempt and $47 \%$ on their second attempt). Significant differences were evident by region of training: the highest pass rates achieved by UK/Ireland (95\%), South Africa (86\%) and North America (86\%) candidates, and the lowest by those trained in Other Americas (67\%), South East AsiaOther (70\%) and East Europe (70\%). Possession of training/ registration in medical systems directly comparable to Australia's was highly advantageous. Further significant findings related to candidates' recency of medical training, age and English language ability. (For example $83 \%$ of candidates attempting the MCQ within 4 years of medical graduation passed it, compared to just $68 \%$ who had qualified 20 or more years earlier.) Comparable findings existed for the Clinical Examination (CE), which had an $86 \%$ overall pass rate (again largely achieved in two sittings). When compared with doctors from Englishspeaking background regions, doctors with a European background (most at that time from South East and East Europe) were 38\% less likely to pass the CE, those from Asia- 
Commonwealth countries $25 \%$ less likely to pass, and those from all other world regions $48 \%$ less likely to pass. Doctors from North Africa/Middle East however were just as likely to pass as those from English-speaking regions (Hawthorne et al, 2007). (See Table 4.)

Table 4: Predicting Passing the Australian Medical Council Clinical Examination After Completion of the MCQ (1978-2005)

\begin{tabular}{|c|c|c|c|c|c|}
\hline & \multirow[b]{2}{*}{ Base value } & \multirow[b]{2}{*}{ Comparator levels } & \multirow[t]{2}{*}{ OR } & \multicolumn{2}{|c|}{$95 \% C I$} \\
\hline & & & & Lo & Hi \\
\hline \multirow[t]{3}{*}{ Age (years) } & $20-29$ & $30-39$ & 0.79 & 0.66 & 0.94 \\
\hline & & $40-49$ & 0.35 & 0.27 & 0.45 \\
\hline & & $50+$ & 0.14 & 0.09 & 0.22 \\
\hline \multirow[t]{5}{*}{ English test status } & Pre-OET passed & Pre-OET unknown & 0.06 & 0.04 & 0.08 \\
\hline & & IELTS/PLAB & 0.23 & 0.20 & 0.27 \\
\hline & & NZREX & 0.60 & 0.34 & 1.07 \\
\hline & & OET/Prov. OET & 0.38 & 0.34 & 0.44 \\
\hline & & USMLE (ECFMG) & 0.67 & 0.47 & 0.96 \\
\hline \multirow{4}{*}{$\begin{array}{l}\text { Time since } \\
\text { qualification }\end{array}$} & $0-4$ years & 5-9 years & 1.10 & 0.93 & 1.31 \\
\hline & & $10-14$ years & 0.96 & 0.80 & 1.17 \\
\hline & & $15-19$ years & 1.22 & 0.94 & 1.59 \\
\hline & & $20+$ years & 1.43 & 1.02 & 1.98 \\
\hline \multirow[t]{4}{*}{ Region of origin } & $\begin{array}{l}\text { English-speaking } \\
\text { background }\end{array}$ & Europe & 0.60 & 0.47 & 0.78 \\
\hline & & N. Africa \& M. East & 0.93 & 0.72 & 1.19 \\
\hline & & Asia-Commonwealth & 0.73 & 0.58 & 0.93 \\
\hline & & Other & 0.51 & 0.40 & 0.65 \\
\hline
\end{tabular}

Statistics:

Logistic regression: -2LL: 8808.61, \% correctly classified: 68\%. Source: The Registration and Training Status of Overseas Trained Doctors in Australia (2007), L Hawthorne, G Hawthorne and B Crotty, Department of Health and Ageing, Canberra, Chapter 3, based on analysis of Australian Medical Council data.

From 2007, responding to increasing source country diversity and rapid growth in temporary migration, the Australian Medical Council introduced four alternative pathways to medical registration (fast track, medium track, slow track, and specialist track). Its aim was to more flexibly manage what had become a highly demand-driven migration process (McLean and Bennett, 2008). Five key points should be noted.

- First, this strategy was wholly initiated and implemented by the national medical assessment authority (following decades of calls for FQR reform).

- Second, empirical data were used to develop alternative medical registration pathways - a process facilitated by the Australian Medical Council's (AMC) longstanding commitment to electronic record-keeping.

- Third, Australia's fast-track Competent Authority pathway (CA) was designed to transit international medical graduates from partial to full registration within a year, while medically employed and without the necessity to sit exams.

- Fourth, within this model IMGs' country of qualification was deemed less important than where they had gained registration. Candidates from over 55 countries of training were eligible to participate, with four examination and two accreditation systems approved (UK, Ireland, Canada, USA and New Zealand). 
- Fifth, doctors accredited by one of these systems, with at least 12 months postexamination practice in a CA country, were eligible to work with light-touch supervision - securing registration after a year from the Medical Board of Australia.

Reform outcomes: Empirical data informed the establishment of Australia's Competent Authority pathway, to which IMGs' response has been immediate and extraordinarily positive. In its first two years of implementation over 4,000 candidates were processed - both temporary and permanent migrants. Two-thirds were deemed eligible, and wholly removed from the examination process (significantly reducing bottlenecks, and increasing immediate employment outcomes). (See Table 5.) By 2011 57\% of medical migrants (selected across all immigration categories) were employed in their field within five years, compared to $41 \%$ two decades earlier (Hawthorne, 2014; Birrell and Hawthorne, 1996). Simultaneously the CA pathway increased Australia's attraction as a global destination. For example over 2,000 UK doctors migrated in the first two years, compared to around 50 annually prior to the CA's introduction. In 2012-13 (the latest available data) 1,123 applicants were fast-tracked, compared to 2,885 MCQ and 2,252 Clinical candidates undertaking the Australian Medical Council examination pathway (Australian Medical Council, 2014).

Table 5: Australian Medical Council Competent Authority Pathway Outcomes by Top 10 Countries of Training (2007- 2010)

\begin{tabular}{|l|r|r|r|}
\hline Country of Training & $\begin{array}{r}\text { Receipt of Application } \\
(\mathbf{N o .})\end{array}$ & $\begin{array}{r}\text { Advanced Standing } \\
\text { Cert. Issued }\end{array}$ & $\begin{array}{r}\text { AMC Certificate } \\
\text { Issued }\end{array}$ \\
\hline 1. UK & 2784 & 1976 & 1019 \\
\hline 2. Ireland & 631 & 483 & 176 \\
\hline 3. India & 575 & 290 & 422 \\
\hline 4. Pakistan & 146 & 83 & 78 \\
\hline 5. USA & 96 & 63 & 9 \\
\hline 6. Sri Lanka & 84 & 60 & 8 \\
\hline 7. Canada & 84 & 60 & 8 \\
\hline 8.Myanmar & 55 & 22 & 44 \\
\hline 9. Iraq & 48 & 30 & 18 \\
\hline 10. Bangladesh & 42 & 22 & 22 \\
\hline 11. Other countries & 423 & 260 & 167 \\
\hline Total & $\mathbf{4 9 5 5}$ & 3327 & $\mathbf{2 0 0 9}$ \\
\hline
\end{tabular}

Source: Hawthorne, L. ( 2012), Health Workforce Migration to Australia - Policy Trends and Outcomes 20042010, Health Workforce Australia, Adelaide, Table 31, based on analysis of Australian Medical Council data.

\section{CASE STUDY 2 (MEDICINE) - EXPLOITING E-TECHNOLOGIES FOR OPERATIONAL REFORM}

The second case study assesses the extent to which the technological revolution creates scope for global partnerships, and the exploitation of e-technologies to improve foreign qualification assessment processes. The Australian Medical Council now utilizes the USA Educational Commission for Foreign Medical Graduates (ECFMG) for document verification, given its possession of a vast global medical school database. Additional electronic opportunities are rapidly emerging, including the development of e-portfolios which the AMC will also use. A prospective medical migrant can lodge documents to the ECFMG in advance for verification purposes, with the outcome housed on a portal to allow instant candidate and authorised stakeholder access through a unique number, with no capacity for report falsification. 
E-technologies are similarly transforming examination processes, with global strategies now varying markedly in terms of exam location (whether delivered on and/or offshore), frequency of administration, mode (whether pen and paper and/or e-based), number of attempts allowed, and sequence (in assessing theoretical knowledge compared to clinical skills). Since 2008 the Australian Medical Council has worked with Pearson on written exam administration (an international test provider delivering around 5000 different test applications globally, and particular expertise related to multiple choice testing). Refined test options have evolved - including the use of adaptive testing, in which the test is tailored to the performance of an individual candidate, with future examination results to be deliverable 'on the final keystroke' (Frank, 2012-13).

In 2013, responding to the criticisms of the 2010-12 parliamentary review of barriers to IMG accreditation (in particular the timeliness, transparency and reliability of assessment procedures), the AMC established the National Medical Testing Centre in Melbourne. This was supported by \$A2 million in federal government funding. Developed to improve operational processes, and leverage off e-technologies, the Centre's aim was to dramatically reduce backlogs for candidates ineligible for the Competent Authority pathway, while making assessment fairer and more efficient. In 2011-12 the AMC had received 7,000 applicants from 3,400 IMGs to sit exams, in a context where it could offer just 1,500 annual examination places. The Centre, by contrast, has 20 clinical examination stations able to operate three times a day, introducing greatly improved transparency and monitoring of processes. Applying state of the art examination technology to the clinical assessment of international medical graduates and other health professionals, the Centre caters to small candidate groups while using 'advanced technology such as multi-media and CCTV recording capability that is not technically possible in hospital-based systems'. Most notably, according to the AMC:

The (Centre can be used) for developing examination materials and stations and items, and particularly in examiner training and calibration. (Partner bodies) can set up pilot exams in the test centre, film them and use the films to calibrate their examiners... We can bring images to examination programs so that they can get high frequency video feeds and media, and use that instead of needing to have an actual patient in the room... Trained 'patients' are used, in addition to genuine patients 'with stable signs'. Structured cases are framed around these. The candidate is assessed by an examiner in a room, either with a role play patient or a simulated patient. Full scale simulations will be used further down the track. A relationship is being established with a US group specializing in that type of assessment (Frank, 2012-13).

Additional options are being developed:

- Through partnership with Pearson involving the use of computers to do all testing and evaluate clinical judgement.

- Using iPad-type tablets to score the clinical exam, creating the capacity to analyse the performance of both examiner and the candidate in real time. ('This data will be captured back through Pearson, and in the course of capturing that we are bringing it back to the AMC... to perform a series of statistical and performance analyses on the examination and on all those who pass the exam.')

- Improving appeal processes and consistency of assessment. ('We have designed the [Test Centre] in such a way that for example we can run 10 stations with examiners in them and in the other six stations we simply record the interaction between the candidate and the patient in a very structured way. And then an examiner sitting in 
Brisbane or Adelaide in their own time can access that recording and score the candidate. Once we start doing that, you have suddenly brought massive efficiency into your exam process.')

- Improving examiner monitoring. ('If there is any anomaly in the examiner you can actually see it in the process of the exam itself. That's the idea of remote scoring.') (Frank, 2012-13).

Reform outcomes: These operational reforms are in the process of significantly reducing medical candidate waitlists, while improving the transparency and consistency of outcomes.

\section{CASE STUDY 3 (HEALTH) - REVIEWING THE IMPACT OF ENGLISH TESTING ON ACCESS TO REGISTRATION}

The third case study concerns the impact of English language assessment on migrants' access to registration - an issue minimally explored in the global literature to date, yet the most powerful determinant in Australia of migrants' recognition and employment outcomes. As demonstrated by Tables 7 and 8, source countries for skilled migrants have become highly diverse - posing serious challenges to regulatory bodies. Australian employers demonstrate a marked preference for native or advanced English-speaking workers qualified in OECD countries (in line with employers in Canada and New Zealand). In the year to June 2014, for instance, 55\% of the top ten employer-sponsored temporary engineers were native English speakers, compared to just 8\% selected through the government's permanent skilled migration category.

Table 6. Top 10 Source Countries for Skilled Category Permanent Migrant Primary Applicants to Australia by Select Field (30 June 2009-2014)

\begin{tabular}{|l|l|l|}
\hline Engineering & Medicine & Nursing \\
\hline Permanent Skilled Category & & \\
\hline India (21\%) & UK (26\%) & UK (21\%) \\
\hline China (12\%) & Malaysia (14\%) & India (17\%) \\
\hline Iran (10\%) & India (11\%) & China (15\%) \\
\hline Malaysia (9\%) & Canada (7\%) & Philippines (10\%) \\
\hline UK (5\%) & Pakistan (5\%) & Nepal (6\%) \\
\hline Sri Lanka (5\%) & Singapore (4\%) & South Korea (6\%) \\
\hline Pakistan (4\%) & Sri Lanka (4\%) & Ireland (3\%) \\
\hline Philippines (3\%) & Ireland (4\%) & Zimbabwe (2\%) \\
\hline South Africa (3\%) & Myanmar (3\%) & Malaysia (2\%) \\
\hline Bangladesh (3\%) & Iran (2\%) & Hong Kong (2\%) \\
\hline Total (all sources) $\mathbf{= 2 7 , 2 8 7}$ & Total (all sources) $\mathbf{= 5 , 4 8 4}$ & Total (all sources) $\mathbf{9 , 7 7 0}$ \\
\hline
\end{tabular}

Source: Analysed of unpublished visa data provided by the Department of Immigration and Border Protection (August 2014). *Please note, 457 visa data adds each total stock by year.

From 1993 Australia mandated English language testing for skilled migrants in 112 'occupations requiring English' - subsequently extended to all fields. By 2007 International English Language Testing System (IELTS) scores of Band 6 were required to migrate (raised from Band 5), or Grade B on Australia's health-specific Occupational English Test (OET). From 2009 higher levels were set by the immigration department, where regulatory 
bodies specified these. Forty-eight in Australia mandated IELTS or OET standards for registration at this time, ranging from IELTS Band 8 in law, to Band 7-7.5 in health, 6 in engineering, but no minimal standard set for accounting.

Table 7. Top 10 Source Countries for Temporary 457 Visa Migrant Primary Applicants to Australia by Select Field (Year to 30 June 2014)

\begin{tabular}{|l|l|l|}
\hline Engineering & Medicine & Nursing \\
\hline Temporary 457 Visa Stock* & & \\
\hline UK (24\%) & UK (31\%) & UK (27\%) \\
\hline Ireland (13\%) & India (10\%) & India (26\%) \\
\hline USA (9\%) & Malaysia (7\%) & Philippines (19\%) \\
\hline India (6\%) & Sri Lanka (6\%) & Ireland (13\%) \\
\hline Philippines (5\%) & Ireland (5\%) & Zimbabwe (2\%) \\
\hline Canada (4\%) & Canada (5\%) & China (1\%) \\
\hline France (4\%) & Pakistan (5\%) & South Africa (1\%) \\
\hline China (4\%) & Iran (5\%) & Canada (1\%) \\
\hline South Africa (2\%) & South Africa (2\%) & USA (1\%) \\
\hline Malaysia (2\%) & Philippines (2\%) & South Korea (1\%) \\
\hline Total (all sources) $\mathbf{= 6 , 1 6 0}$ & Total (all sources) $\mathbf{4 , 1 6 0}$ & Total (all sources) $\mathbf{3 , 8 1 0}$ \\
\hline
\end{tabular}

Source: Analysed of unpublished visa data provided by the Department of Immigration and Border Protection (August 2014). *'Stock resident' counts those employed in Australia that year. Successive years cannot be totalled by field, as migrants may stay up to four years, and also extend this.

By 2012 English language ability had become Australia’s key criterion for skilled migrant selection, along with qualification level and employer sponsorship. Despite this trend, minimal scientific evidence was available to inform standard-setting by field. For example of 73 Research Reports published by the IELTS Cambridge consortium, just four addressed English standards for professional regulation purposes (on an audit rather than a fieldspecific validation basis). According to the author of two such reports, there was an inherent danger in regulatory body requirements, in a context where IELTS had been designed to assess international students' capacity to study in English, and:

The question of whether (it) is appropriate for testing broader skills such as those required for a professional operating as a doctor, nurse, veterinary surgeon, engineer, teacher or accountant arises because there is little research available which focuses on validating the testing system for these purposes (Merrifield, 2012: 9).

In 2010 the Council of Australian Governments established the Australian Health Practitioner Regulation Agency (AHPRA), with National Boards governing all major fields (including medicine). This represented a radical shift to uniformity, proscribing national registration standards and scopes of practice. Given the variability of English language standards at this time, an early AHPRA priority was to benchmark 'inherited' Australian against global requirements, and to explore the evidence base for standard-setting. An eight country comparative study was commissioned in 2013, involving an extensive literature review, 59 interviews with key regulatory body stakeholders (Australia, Canada, Ireland, New Zealand, Singapore, the UK and the US), and analysis of results for 30,000 migrant candidates taking Australia's health-specific Occupational English Test from 2007-11 (Hawthorne \& To, 2013). (IELTS results were not available for independent analysis). Key issues of concern to migrant professionals included whether candidates should be obliged to pass reading, writing, 
listening and speaking tests at a single sitting; whether it was fair for pharmacy to mandate a higher English standard than medicine or allied health fields (as was then the case); and whether former international students qualified in Australia should be entitled to test exemptions. Three key findings should be noted from this research - the most extensive international investigation of the issue to date.

First, global bodies by 2013 had adopted markedly different English language standards for registration, specifying:

- Few or multiple tests for migrant health professionals

- Different test types (ranging from generic tests such as the IELTS or Test of English as a Foreign Language [TOEFL], to field-specific tests, to embedded assessment, to interviews)

- Different test scores by field

- Different pass timeframes (ranging from the requirement to pass all four sub-tests at a single attempt compared to multiple sittings)

- Different lengths of result currency (from six months to two years)

- Different categories of test exemptions (including in relation to native English speakers and former international students)

Second, there was a dearth of field-specific empirical research to inform such policy on English language standards for registration. Most of the 59 global regulators interviewed revealed modest to nil knowledge as to why specific test requirements or standards existed (comments including that these were 'heritage' decisions 'lost in the mists of time', that 'the test administrators/ experts advised this', or that 'my predecessor might know').

Third, English language testing was found to exert an extraordinary impact on migrant health professionals' registration in Australia - exceeding that of theoretical or clinical examinations, based on analysis of 30,000 results from 2007-11. Just $17 \%$ of nurse candidates passed the Occupational English Test in 2011 on first or subsequent attempts, compared to $62 \%$ of dentists, 52\% of doctors and $37 \%$ of pharmacists. (See Figure 1.) Extraordinary differences by candidate country of training prevailed. In nursing, for example, pass rates ranged from $43 \%$ of UK and $33 \%$ of German candidates, to $20 \%$ of candidates from Japan, 11\% each from the Philippines and India, and just 4\% from China. The modest reading and writing pass rates of UK candidates raised questions about test and standard appropriacy, given that most such candidates were native English speakers (Hawthorne \& To, 2013).

Reform outcomes: In response to the review findings, following a call for public submissions and consideration by the National Boards, AHPRA's English language skills registration standards were modified mid-2015. A greater range of test exemptions have been allowed, the mandated pharmacy standard lowered (to align with other health fields), and candidates permitted to meet the required English standard within six months on two rather than one sitting (AHPRA, 2015). These reforms seem certain to result in more positive candidate outcomes. 
Figure 1: Occupational English Pass Rates for Migrant Health Professionals in Australia by Select Field, (2005, 2010, 2011)

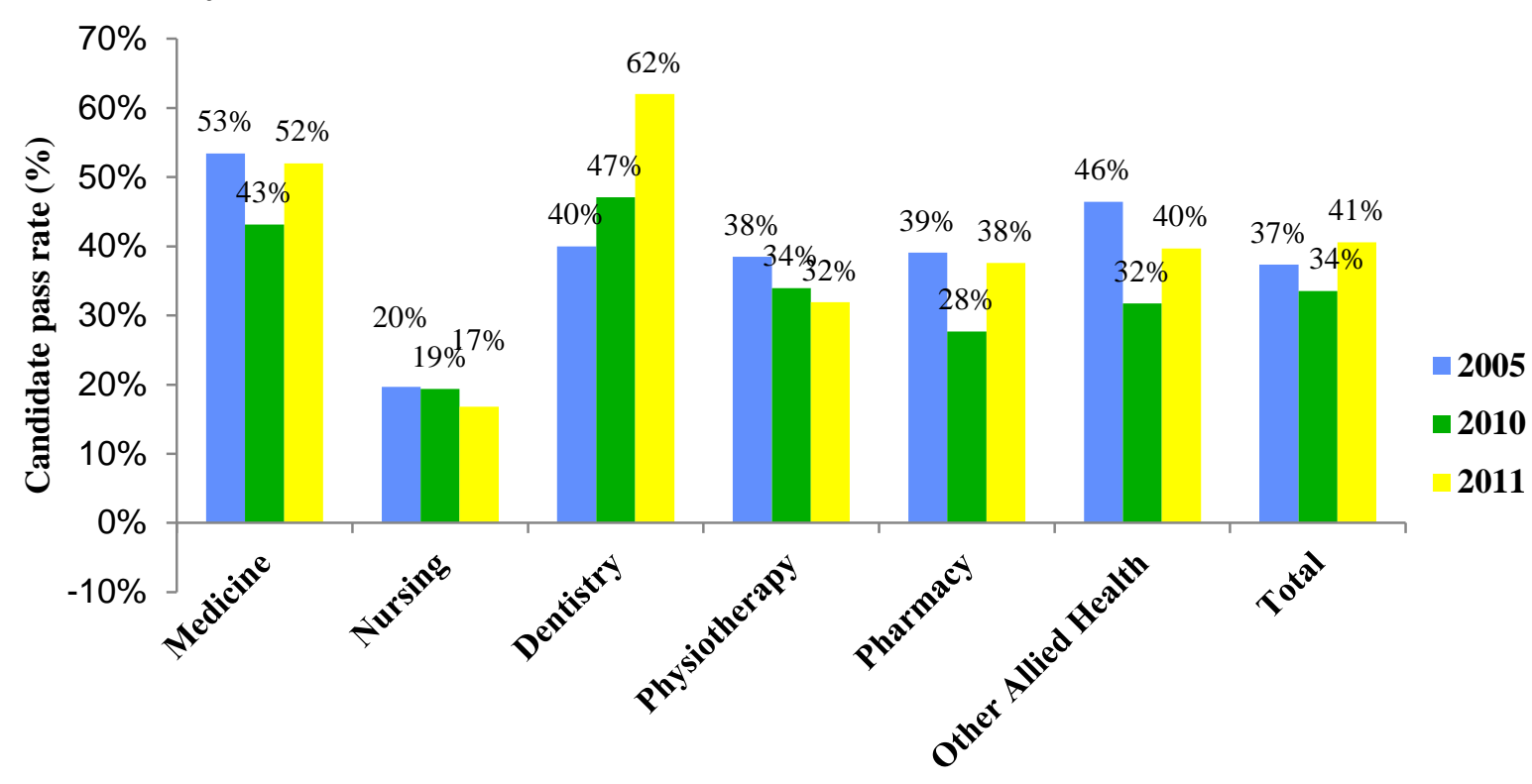

Source: Hawthorne, L \& To, A (2013), English Language Skills Registration Standards - An Australian and Global Comparative Assessment, Australian Health Practitioner Regulation Agency, Melbourne

\section{CONCLUSION - THE IMPACT OF QUALIFICATION RECOGNITION REFORM IN AUSTRALIA AND POLICY LESSONS}

Overall, it is methodologically challenging to assess the impact of Australian qualification recognition reform on migrants' early employment outcomes. Important initiatives exist in a range of additional fields, including regulator-driven processes in accounting and engineering ${ }^{i i}$. Developments across the board however are uneven. Further, the Australian government has made multiple changes to skilled migrants' selection - beyond qualification screening finetuning English language testing, the study-migration pathway, employer sponsorship, and assessment of labour market demand.

Despite this complexity, and the dramatic recent diversification of migrant source countries, analysis of Australia's 2011 Census data demonstrated that $66 \%$ of $2006-11$ nurse arrivals were employed in their field within 5 years (compared to $43 \%$ in 1996), 57\% of doctors (compared to 41\%), 29\% of engineers (compared to 17\%), and $22 \%$ of accountants (compared to 24\%, in a context where by 2011 accounting was grossly oversupplied by former international students) (Birrell \& Hawthorne, 1999). These Census data include migrants admitted across all immigration categories.

As demonstrated by Table 8, skilled category migrants' employment outcomes have also substantially improved in the recent period, beyond differences attributable to the economic cycle. From 2009-11 81\% of permanent skilled category arrivals were fully employed at twelve months, compared to around 60\% in the mid-1990s (Department of Immigration and Citizenship, 2012; Hawthorne, 2008). Seventy-three percent of those employed were immediately using their qualifications in work, rising to $91 \%$ for employer-sponsored migrants. Wage rates had risen - vastly exceeding those of family principal applicants who arrive unscreened for recognition, and were far less likely to be using their qualifications in 
work (23\%). Australia's qualification recognition reforms seem certain to have contributed to these outcomes, with additional refinements in train. As demonstrated by the present paper in relation to health, new data sources are also becoming available for analysis, allowing researchers to evaluate the impact of specific innovations.

Table 8: Percentage Employment Outcomes at 6 and 12 Months for Primary Applicant Permanent Skilled Migrants by Sub-Category (2009-2011)

\begin{tabular}{|c|c|c|c|c|c|c|c|}
\hline $\begin{array}{l}\text { Sub-Category } \\
\text { @ } 6 \text { Months }\end{array}$ & $\begin{array}{r}\text { Skilled } \\
\text { Job }\end{array}$ & $\begin{array}{l}\text { Other } \\
\text { Job \% }\end{array}$ & $\begin{array}{r}\text { Not } \\
\text { Working }\end{array}$ & $\begin{array}{l}\text { Working } \\
\text { Full-time }\end{array}$ & $\begin{array}{r}\text { Participation } \\
\text { Rate }\end{array}$ & $\begin{array}{r}\text { \$A Median } \\
\text { Full-time } \\
\text { Earnings }\end{array}$ & Unemploy. \\
\hline $\begin{array}{l}\text { Employer } \\
\text { Sponsored }\end{array}$ & 90 & 7 & 3 & 92 & 98 & 71,300 & 0.5 \\
\hline $\begin{array}{l}\text { Family/ State } \\
\text { Sponsored }\end{array}$ & 60 & 31 & 9 & 72 & 98 & 50,000 & 7 \\
\hline $\begin{array}{l}\text { Offshore } \\
\text { Independent }\end{array}$ & 75 & 12 & 12 & 76 & 97 & 74,600 & 10 \\
\hline $\begin{array}{l}\text { Onshore } \\
\text { Independent }\end{array}$ & 55 & 37 & 8 & 69 & 98 & 44,400 & 6 \\
\hline $\begin{array}{l}\text { Skilled } \\
\text { Graduates }\end{array}$ & 58 & 36 & 5 & 65 & 98 & 40,000 & 3 \\
\hline $\begin{array}{l}\text { All Skilled } \\
\text { Category }\end{array}$ & 68 & 24 & 8 & 75 & 96 & 52,000 & 5 \\
\hline $\begin{array}{l}\text { All Family } \\
\text { Category }\end{array}$ & 21 & 28 & 18 & 33 & 28 & 43,000 & 67 \\
\hline $\begin{array}{l}\text { Sub-Category } \\
\text { @ } 12 \text { Months }\end{array}$ & $\begin{array}{r}\text { Skilled } \\
\text { Job }\end{array}$ & $\begin{array}{l}\text { Other } \\
\text { Job \% }\end{array}$ & $\begin{array}{r}\text { Not } \\
\text { Working }\end{array}$ & $\begin{array}{l}\text { Working } \\
\text { Full-time }\end{array}$ & $\begin{array}{r}\text { Participation } \\
\text { Rate }\end{array}$ & $\begin{array}{r}\text { \$A Median } \\
\text { Full-time } \\
\text { Earnings }\end{array}$ & $\begin{array}{r}\text { Unemploye } \\
\text { d }\end{array}$ \\
\hline $\begin{array}{l}\text { Employer } \\
\text { Sponsored }\end{array}$ & 91 & 7 & 1 & 93 & 99 & 75,000 & 0.5 \\
\hline $\begin{array}{l}\text { Family/ State } \\
\text { Sponsored }\end{array}$ & 65 & 28 & 7 & 78 & 97 & 55,000 & 4 \\
\hline $\begin{array}{l}\text { Offshore } \\
\text { Independent }\end{array}$ & 83 & 10 & 7 & 85 & 96 & 79,000 & 3 \\
\hline $\begin{array}{l}\text { Onshore } \\
\text { Independent }\end{array}$ & 61 & 33 & 6 & 77 & 97 & 47,000 & 3 \\
\hline $\begin{array}{l}\text { Skilled } \\
\text { Graduates }\end{array}$ & 62 & 32 & 6 & 74 & 96 & 41,600 & 2 \\
\hline $\begin{array}{l}\text { All Skilled } \\
\text { Category }\end{array}$ & 73 & 22 & 6 & 81 & 96 & 56,000 & 2 \\
\hline $\begin{array}{l}\text { All Family } \\
\text { Category }\end{array}$ & 23 & 30 & 11 & 35 & 17 & 44,200 & 65 \\
\hline
\end{tabular}

Source: Adapted from Department of Immigration and Citizenship (2012), 'The Continuous Survey of Australia's Migrants: Cohorts 1 to 5 Report 2009-11', Canberra, Skilled category data adapted from Table 3.1 (p. 13) with Family category data derived from Table 1.1 (p. 8).

In the twenty-first century foreign qualification recognition has become fundamental to effective human capital transfer. Outcomes in destination countries are influenced by a range of competing values, including:

1. Global competition for human capital - spurring under-supplied countries/ regions to recruit/ retain skilled migrants through relatively flexible registration standards.

2. Efficiency - maximising the utilisation and retention of international professionals (particularly those who are sponsored). 
3. Social justice - reflecting national/ state human rights-based reform agendas designed to liberalise migrants' access to registration.

4. Commitment to bilateral or multilateral agreements - intended to facilitate trade in goods and services, supported by mutual foreign credential recognition.

5. Protection of public safety - the prime value to which the majority of regulatory bodies adhere.

The first two goals have arguably been paramount for the Australian government and employers in recent decades, and driven FQR policy reform. The fifth remains core to regulatory bodies' mission, but in a marked shift from professional protectionism a range of regulators are now devising, implementing and leading (rather than resisting) change.

Based on Australia's FQR experience, there are five key policy learnings of potential relevance to Canada. First, it has been broadly recognised that changed migration modes mandate more flexible FQR pathways in the age of globalisation. Second, federal leadership and funding have been fundamental to catalysing and sustaining Australian reform. Third, parliamentary oversight has been critical to ensuring surveillance, supported by an insistence on demonstrably improved FQR outcomes. Fourth, leading regulators have showcased the value of exploiting e-technologies, global partnerships, and the use of empirical evidence to transform their assessment procedures. Finally, independent research has remained central to Australian policy reform, driving the participation of key stakeholders.

\section{REFERENCES}

Australian Health Practitioner Regulation Agency. 2011. 'About AHPRA', http://www.ahpra.gov.au/About-AHPRA.aspx, accessed 11 February 2011.

Australian Health Practitioner Regulation Agency. 2011. 'AHPRA FAQ: What is the National Law?’ https://www.ahpra.gov.au/Support/FAQ.aspx, accessed 19 April 2015.

Australian Health Practitioner Regulation Agency. 2015. Range of documents regarding revised English language skill registration standards, http://www.ahpra.gov.au/Registration/Registration-Standards/English-language-skills.aspx, accessed 10 June 2015.

Australian Medical Council. 2011. Submission to the House of Representatives Standing Committee on Health and Ageing on the Inquiry into Registration Processes and Support for Overseas Trained Doctors. AMC. Canberra.

Australian Medical Council. 2013. 'Australia Opens First National Medical Testing Centre', Media Release, http://www.amc.org.au/images/MediaRelease/2013/Media\%20ReleaseOpening-of-AMC-National-Medical-Test-Centre-31-July-2013.pdf.

Australian Medical Council. 2014. Annual Report 2013. AMC. Canberra.

Birrell, R. 2004. 'Australian Policy on Overseas-Trained Doctors'. MJA 181(11) 635.

Birrell, R. and Hawthorne, L. 1996, Immigrants and the Professions in Australia. Centre for Population and Urban Research. Monash University. Melbourne.

Birrell, R. and Hawthorne. L. 1999. 'Australia’s Skilled Migration Program Outcomes as of 1996'. Review of the Independent and Skilled-Australian Linked Categories, Appendix 1. Department of Immigration and Multicultural Affairs. Canberra.

Chiongma, E (2012), 'Nursing Bridging Program Matrix', results of unpublished Australiawide audit provided to L Hawthorne, Melbourne. 
Committee of Inquiry into Recognition of Overseas Qualifications (CIROQ) (1983), The Recognition of Overseas Qualifications in Australia, Vols 1 \& 2, Australian Government Publishing Service, Canberra.

Department of Education and Training. 2015. 'Country Education Profiles'. Australian Government. Canberra. https://internationaleducation.gov.au/Services-AndResources/services-for-organisations/Pages/Services-for-organisations.aspx, accessed 15 June.

Department of Employment Education and Training. 1992. A Guide to the Development of Competency Standards for Professions, Research Paper No 7, April, Australian Government Publishing Service, Canberra

Department of Immigration and Border Control (2014). Analysis of unpublished immigration arrivals data for permanent compared to temporary skilled migration categories, provided August 2014.

Department of Immigration and Citizenship. 2012. 'The Continuous Survey of Australia's Migrants: Cohorts 1 to 5 Report 2009-11'. Canberra.

Englmann, B. and Muller, M. 2007. Brain Waste - Die Anerkennung von auslandischen Qualifikationen in Deutschland, Tur an Tur Integrationsprojekts gGmbH, TP Global Competences, Germany.

Frank, F. 2012-13. Transcribed interviews on Australian Medical Council assessment developments, conducted with CEO of the Australian Medical Council by L Hawthorne, Canberra (August 2012, November 2013).

Freidson, E. 1986. Professional Powers: A Study of the Institutionalisation of Formal Knowledge, University of Chicago Press, Chicago \& London.

Freidson E. 1994. Professionalism Reborn: Theory, Prophecy, and Policy, Polity Press, Cambridge, United Kingdom.

Gonczi, A., Hager, P., \& Oliver, L. 1990. Establishing Competency-Based Standards in the Professions, National Office of Overseas Skills Recognition, Research Paper No 1, December, Australian Government Publishing Service, Canberra.

Guo, S. 2007. 'Tracing the Roots of Non-Recognition of Foreign Qualifications, Chapter X in Foreign Credential Recognition, Canadian Issues, Association for Canadian Studies, Spring, Ottawa, Association for Canadian Studies, Spring, Ottawa.

Hawthorne, L. 1994. Labour Market Barriers for Immigrant Engineers in Australia. Australian Government Publishing Service. Canberra.

Hawthorne, L. 2002. 'Qualifications Recognition Reform for Skilled Migrants in Australia: Applying Competency-Based Assessment to Overseas-Qualified Nurses', International Migration, Volume 40 (6): 55-92.

Hawthorne, L. 2008. The Impact of Economic Selection Policy on Labour Market Outcomes for Degree-Qualified Migrants in Canada and Australia, Institute for Research on Public Policy, Vol 14 No 5, 2008, Ottawa.

Hawthorne, L. 2012. Health Workforce Migration to Australia - Policy Trends and Outcomes 2004-2010, Health Workforce Australia, Adelaide, http://www.hwa.gov.au/workprograms/international-health-professionals/health-profession-migration.

Hawthorne, L. 2013. 'Recognizing Foreign Qualifications - Emerging Global Trends', Migration Policy Institute, Washington DC, http://www.migrationpolicy.org/pubs/Credentialing-GlobalTrends.pdf.

Hawthorne, L. 2014. 'Health Workforce Migration in Australia'. Chapter 9 in Migration of Health Workers - WHO Code of Practice and the Global Economic Crisis. Eds. A. Siyam and M. Dal Poz. World Health Organization. Geneva. 
Hawthorne, L., G. Hawthorne and B. Crotty. 2007. Final Report: The Registration and Training Status of Overseas Trained Doctors in Australia. Melbourne: University of Melbourne.

Herfs, P. 2011, International Medical Graduates in the Netherlands - A Future of Medical Doctors or Cleaners?, Verlag Dr. Muller GmbH \& Co, Deutschland.

House of Representatives Standing Committee on Community Affairs (HRSCCA). 1996. A Fair Go For All - Report on Migrant Access and Equity. Australian Government Publishing Service. Canberra.

House of Representatives Standing Committee on Health and Ageing. 2012. Lost in the Labyrinth: Report on the Inquiry into Registration Processes and Support for Overseas Trained Doctors. Canberra: The Parliament of the Commonwealth of Australia.

Joint Standing Committee on Immigration. 2006. Negotiating the Maze: Review of Arrangements for Overseas Skills Recognition, Upgrading and Licensing, The Parliament of the Commonwealth of Australia, Australian Government Publishing Service, Canberra.

Iredale, R. 2009. 'Luring Overseas-Trained Doctors to Australia: Issues of Training, Regulating and Trading'. International Migration 47 (4), 31-65.

Joint Standing Committee on Immigration. 2006. Negotiating the Maze: Review of Arrangements for Overseas Skills Recognition, Upgrading and Licensing, The Parliament of the Commonwealth of Australia, Australian Government Publishing Service, Canberra.

McLean, R., and J. Bennett. 2008. "Nationally Consistent Assessment of International Medical Graduates” MJA 188, 464.

Merrifield, G. 2012. 'An Impact Study into the Use of IELTS by Professional Associations and Registration Entities - Canada, the UK and Ireland', IELTS Research Reports, Volume 11, www.ielts.org, accessed 30 July.

National Office of Overseas Skills Recognition. 1994. Issues and Options Paper on the Overseas Skills Recognition Process and Related Labour Market Issues. NOOSR. Canberra. September.

OECD. 2003-2013. SOPEMI Reports, OECD, Paris.

Papademetriou, D. and Sumption, M. 2013. 'Attracting and Selecting from the Global Talent Pool - Policy Challenges’, Migration Policy Institute, Washington.

Schuster, A., Vincenza, M., Desiderio, B. and Urso, G. eds. 2013. Recognition of Qualifications and Competences of Migrants, International Organization of Migration, Brussels.

Siyam, A. and Del Paz, M. Eds. 2014. Migration of Health Workers - WHO Code of Practice and the Global Economic Crisis, World Health Organization, Geneva.

Sumption, M. 2013. 'Tackling Brain Waste - Strategies to the Recognition of Immigrants' Foreign Qualifications', Migration Policy Institute, Washington DC.

World Health Organisation. 2006. Working Together for Health -The World Health Report 2006, WHO, Geneva.

Zurn, P., and J-C. Dumont. 2008. Health Workforce and International Migration: Can New Zealand Compete? Paris: WHO.

'I acknowledge with gratitude funding support from the following bodies for the empirical
research on which two of these case studies were based (Case Study 1: Hawthorne, L.,
Hawthorne, G. and Crotty, B. 2007. The Registration and Training Status of Overseas
Trained Doctors in Australia, commissioned by the Department of Health and Ageing,
Canberra; and Case Study 3: Hawthorne, L. and To, A. 2013. English Language Skills 
Registration Standards - An Australian and Global Comparative Assessment, commissioned by the Australian Health Practitioner Regulation Agency, Melbourne.)

ii In engineering, for example, the national regulator (Engineers Australia) has made a sustained commitment to tertiary sector and regulator capacity-building in immigrant source countries - its goals being to build their case for membership of the Washington Accord, while enhancing post-migration recognition. The Washington Accord is a multinational agreement established in 1989 to facilitate the recognition or equivalency of accredited engineering education programs leading to the engineering degree. Australia is an original signatory. By 2008 there were nine Washington Accord member countries (Hong Kong, the UK, the US, Australia, New Zealand, South Africa, Ireland, Japan and Canada), rising to 17 by 2014 (including Singapore, Malaysia and India - these three representing major migrant engineer source countries for Australia). Australia is also engaged in the Sydney Accord, signed in June 2001, which was designed to establish a comparable system for recognition of the training of engineering technologists. Engineers Australia both endorses and facilitates these processes, with a strong focus on regional capacity-building. 


\section{University Library}

\section{- M M N E R VA A gateway to Melbourne's research publications}

Minerva Access is the Institutional Repository of The University of Melbourne

Author/s:

Hawthorne, L

Title:

The Impact of Skilled Migration on Foreign Qualification Recognition Reform in Australia

Date:

2015-08-01

Citation:

Hawthorne, L. (2015). The Impact of Skilled Migration on Foreign Qualification Recognition Reform in Australia. CANADIAN PUBLIC POLICY-ANALYSE DE POLITIQUES, 41 (Supplement 1), pp.S173-S187. https://doi.org/10.3138/cpp.2015-027.

Persistent Link:

http://hdl.handle.net/11343/59627 